\title{
In Situ Lithiated ALD Niobium Oxide for Improved Long Term Cycling of Layered Oxide Cathodes: A Thin-Film Model Study
}

\author{
Abdessalem Aribia, ${ }^{\mathrm{z}}(\mathbb{D})$ Jordi Sastre, (ii) Xubin Chen, Evgeniia Gilshtein, (i) Moritz H. Futscher, (i) \\ Ayodhya N. Tiwari, and Yaroslav E. Romanyuk (i)
}

Laboratory for Thin Films and Photovoltaics, Empa-Swiss Federal Laboratories for Materials Science and Technology, Überlandstrasse 129, CH-8600 Dübendorf, Switzerland

\begin{abstract}
Protective coatings applied to cathodes help to overcome interface stability issues and extend the cycle life of Li-ion batteries. However, within 3D cathode composites it is difficult to isolate the effect of the coating because of additives and non-ideal interfaces. In this study we investigate niobium oxide $\left(\mathrm{NbO}_{\mathrm{x}}\right)$ as cathode coating in a thin-film model system, which provides simple access to the cathode-coating-electrolyte interface. The conformal $\mathrm{NbO}_{\mathrm{x}}$ coating was applied by atomic layer deposition (ALD) onto thin-film $\mathrm{LiCoO}_{2}$ cathodes. The cathode/coating stacks were annealed to lithiate the $\mathrm{NbO}_{\mathrm{x}}$ and ensure sufficient ionic conductivity. A range of different coating thicknesses were investigated to improve the electrochemical cycling with respect to the uncoated cathode. At a $\mathrm{NbO}_{\mathrm{x}}$ thickness of $30 \mathrm{~nm}$, the cells retained $80 \%$ of the initial capacity after 493 cycles at $10 \mathrm{C}$, more than doubling the cycle life of the uncoated cathode film. Elemental analysis using TOF-SIMS and XPS revealed a bulk and surface contribution of the $\mathrm{NbO}_{\mathrm{x}}$ coating. These results show that in situ lithiated $\mathrm{ALD} \mathrm{NbO}_{\mathrm{x}}$ can significantly improve the performance of layered oxide cathodes by enhancing interfacial charge transfer and inhibiting surface degradation of the cathode, resulting in better rate performance and cycle life.

(C) 2021 The Author(s). Published on behalf of The Electrochemical Society by IOP Publishing Limited. This is an open access article distributed under the terms of the Creative Commons Attribution 4.0 License (CC BY, http://creativecommons.org/licenses/ by/4.0/), which permits unrestricted reuse of the work in any medium, provided the original work is properly cited. [DOI: 10.1149/ 1945-7111/abf215]
\end{abstract}

Manuscript submitted January 24, 2021; revised manuscript received March 17, 2021. Published April 7, 2021.

Supplementary material for this article is available online

Engineering of artificial solid-electrolyte interfaces in lithium ion batteries is a common strategy to improve a wide span of characteristics, including capacity, rate capability and cycle life. ${ }^{1-3}$ By using an artificial solid-electrolyte interface for layered intercalation cathodes such as $\mathrm{LiCoO}_{2}$ and $\mathrm{LiNi}_{1-\mathrm{y}-\mathrm{z}} \mathrm{Mn}_{\mathrm{y}} \mathrm{Co}_{\mathrm{z}} \mathrm{O}_{2}$, the decay of the electrochemical performance can be decelerated and the power performance enhanced. ${ }^{4,5}$ This is possible due to the suppression of redox-active metal dissolution from the cathode into the electrolyte and prevention of the formation of a resistive native layer at the cathode-electrolyte interface. ${ }^{6,7}$ The employed coatings for this purpose are usually either organic polymers (e.g. polypyrrole ${ }^{8}$ ) or inorganic materials. Inorganic coatings, such as metal oxides, are thermally and mechanically stable, nonflammable and normally display little to no reactivity with the cathode itself. ${ }^{9}$ The function of the coating depends on the type: $\mathrm{Li}^{+}$conducting materials elevate the ionic diffusion coefficient and thus enhance the rate performance, electronic conductors like graphene allow for improved electronic conductivity across the interface and lastly, oxides, fluorides and other inert materials construct a protective layer and reduce interactions between cathode and electrolyte. ${ }^{10}$

The family of niobium oxides (e.g. $\mathrm{Nb}_{2} \mathrm{O}_{5}$ ) and their lithiated form (e.g. $\mathrm{LiNbO}_{3}$ ) have found several applications in the field of lithium ion batteries. This type of material, which will be denoted as $\mathrm{NbO}_{\mathrm{x}}$ in the rest of the manuscript, can function as electrode ${ }^{11}$ and electrolyte $^{12}$ but its most interesting application is as cathode coating. ${ }^{13,14}$ Lithiated $\mathrm{NbO}_{\mathrm{x}}$ processed by atomic layer deposition (ALD) possesses an ionic conductivity of $10^{-9} \mathrm{~S} \mathrm{~cm}^{-112}$ and is electrochemically stable in combination with layered oxide cathode materials, such as $\mathrm{LiCoO}_{2}$ (LCO). ${ }^{15,16}$ Deposited on a cathode material, $\mathrm{NbO}_{\mathrm{x}}$ can play a role as protective layer, surface modifier and bulk dopant. As a protection coating, it can reduce side reaction and improve structural stability. Interdiffusion on the other hand can increase the stability at the interface by decreasing defects and oxygen loss. 5

$\mathrm{NbO}_{\mathrm{x}}$ is commonly used to inhibit electrochemical decomposition of sulfide solid electrolytes or prevent interdiffusion during high temperature processing of oxide electrolytes. ${ }^{13,17}$ Sol-gel

${ }^{\mathrm{z}}$ E-mail: abdessalem.aribia@empa.ch coating of $\mathrm{LiNbO}_{\mathrm{x}}$ on commercial LCO powder, followed by high temperature treatment at $800{ }^{\circ} \mathrm{C}$, was previously used to increase cycle ability ${ }^{18}$ but it was difficult to distinctly identify the interface effects. Therefore, to investigate the effects of $\mathrm{NbO}_{\mathrm{x}}$ coating on the cathode-electrolyte interface, a thin-film approach is advantageous as it offers a simplified and pure model system without the need for binders and additives. Kato et al. ${ }^{14}$ demonstrated this approach by coating a thin-film LCO cathode with $350 \mathrm{~nm} \mathrm{LiNbO}$ by pulsedlaser deposition (PLD) and observed that the coating could enhance the rate performance, obtaining $20 \%$ remaining capacity at $30 \mathrm{C}$. However, since the coating was thicker than the cathode itself, a non-negligible increase in the interfacial impedance is expected as well as difficulties in deconvoluting the effect of the coating from the active material.

The goal of this work is to further deepen the understanding of $\mathrm{NbO}_{\mathrm{x}}$ as a cathode coating with the goal of overcoming current limitations in rate performance and cycle life. Atomic layer deposition as a coating method has the distinct advantage of producing conformal coatings with $\AA$-level thickness control. ${ }^{9}$ This allows the investigation of ultra-thin coatings of $\mathrm{NbO}_{\mathrm{x}}$ for cathodes with different thicknesses, ensuring negligible contribution as active material in the electrochemical investigations. In this work, LCO was employed as a representative layered oxide cathode material as it is a well-studied cathode commonly used in Li-ion batteries and in thin-film configuration it possesses comparable performance to the widely employed bulk cathodes made from powders. ${ }^{19}$

\section{Methods}

LCO electrode preparation.-The thin-film half cells were prepared on single-side polished sapphire (0001) wafers (University Wafers). The close thermal expansion coefficient of sapphire and the deposited films make it more favorable as a substrate than other materials such as $\mathrm{Si}$. First, the sapphire wafers were coated with a $20 \mathrm{~nm}$ Ti adhesion promoter layer and a $300 \mathrm{~nm}$ Pt current collector by RF magnetron sputtering. The sputtering deposition was performed from $\mathrm{Ti}$ and $\mathrm{Pt}$ targets (Plasmaterials Inc.) in an Orion sputtering system (AJA International Inc.) applying a sputtering power of $3 \mathrm{~W} \mathrm{~cm}^{-2}$ at a pressure of $0.3 \mathrm{~Pa}$ and $50 \mathrm{sccm} \mathrm{Ar}$ gas flow. In the same system, $300 \mathrm{~nm}$ LCO films were deposited from stoichiometric 
$\mathrm{LiCoO}_{2}$ targets (Toshima Manufacturing Co.) at room temperature with a power of $5.9 \mathrm{~W} \mathrm{~cm}^{-2}$ and a bias of $70 \mathrm{~V}$ applied to the substrate. Details regarding the LCO thin film preparation are provided by Filippin et al. ${ }^{20}$

$\boldsymbol{N} \boldsymbol{b} \boldsymbol{O}_{\boldsymbol{x}}$ coating by $\boldsymbol{A L D}$. - The as-deposited LCO films were coated with an amorphous $\mathrm{NbO}_{\mathrm{x}}$ layer by ALD at a substrate temperature of $175^{\circ} \mathrm{C}$ with argon as carrier gas at a base pressure of $19 \mathrm{~Pa}$ in a Fiji G2 system (Veeco Instruments Inc.). The precursors were niobium $(\mathrm{V})$ ethoxide $\left(\mathrm{NbOEt}_{5}\right)$ (Sigma Aldrich) and $\mathrm{H}_{2} \mathrm{O}$. $\mathrm{NbOEt}_{5}$ was kept at $160{ }^{\circ} \mathrm{C}$ while $\mathrm{H}_{2} \mathrm{O}$ was unheated. The growth rate was determined by ellipsometry on $\mathrm{Si}(100)$ reference substrates (Fig. S1 (available online at stacks.iop.org/JES/168/040513/ mmedia)) and linear growth was observed with a growth rate of $0.42 \AA$ cycle $^{-1}$. X-ray diffractometry (XRD) confirmed that the asdeposited layers were amorphous. The post-annealing treatment for the $\mathrm{NbO}_{\mathrm{x}}$ coated LCO was carried out at $700{ }^{\circ} \mathrm{C}$ for one hour with a heating rate of $10^{\circ} \mathrm{C} \mathrm{min}^{-1}$ in a tube furnace (Carbolite Gero $\mathrm{GmbH}$ $\&$ Co.) at atmospheric pressure under $\mathrm{O}_{2}$ flow.

Material characterization.-The microstructure of the cathode stack was studied by scanning electron microscopy (SEM) (Hitachi FEG-SEM S-4800). The cross section was prepared by scribing and cleaving the substrate with cleaving pliers. To prevent charging the sample was covered with a $2 \mathrm{~nm} P t$ coating. XRD was performed in grazing-incidence mode using $\mathrm{Cu} \mathrm{K}_{\alpha 1}$ radiation at an incident angle of $\omega=2^{\circ}$ in the range of $2 \theta=10^{\circ}-80^{\circ}$. Phase identification was done by using Profex. ${ }^{21}$ Time-of-flight secondary ion mass spectrometry (ToF-SIMS) (ToF.SIMS ${ }^{5}$, IONTOF) was used to investigate the elemental distribution across the cathode profile. $\mathrm{A} \mathrm{Cs}^{+}$-ion gun with $\mathrm{V}_{\mathrm{ac}}=2 \mathrm{kV}$ and $\mathrm{I}=110 \mathrm{nA}$ was employed to sputter an area of $300 \times 300 \mu \mathrm{m}^{2} . \mathrm{A} \mathrm{Bi}^{+}$ion gun was used as primary ion source $\left(\mathrm{V}_{\mathrm{ac}}=25 \mathrm{kV}\right.$ and $\left.\mathrm{I}=2 \mathrm{pA}\right)$ for analyzing the chemical species on a
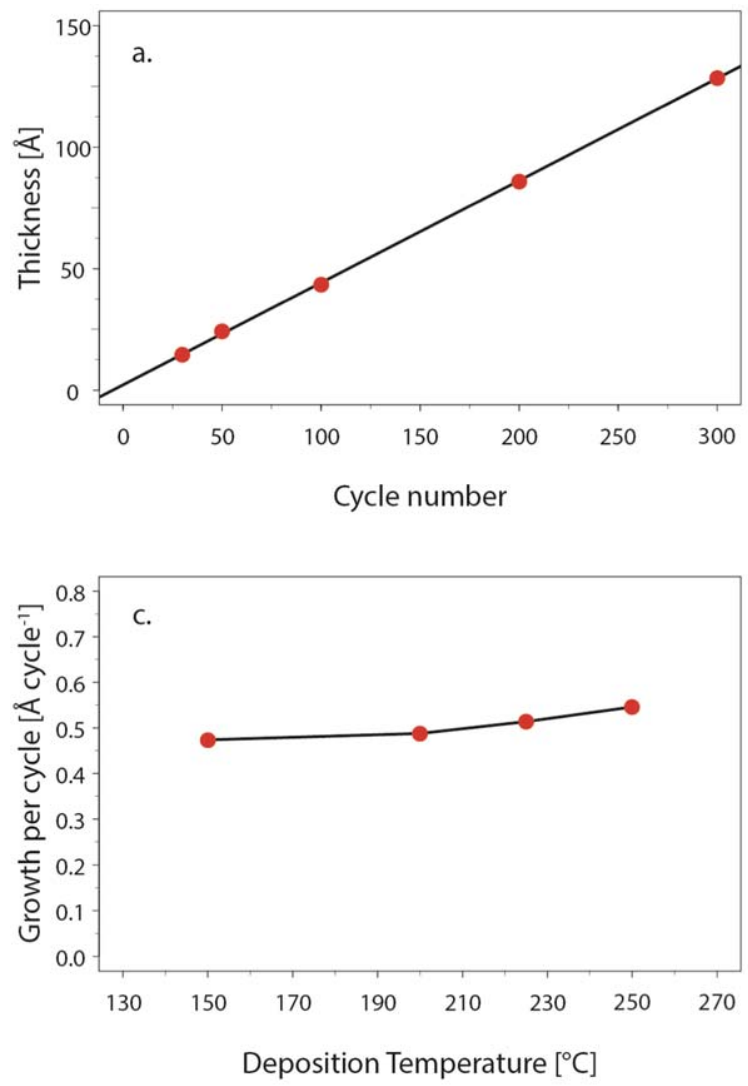

$100 \times 100 \mu \mathrm{m}^{2}$ area within the sputtering crater. A floodgun was used to prevent surface charging. X-ray photoelectron spectroscopy (XPS) measurements were performed using a Quantum2000 photoelectron spectrometer from Physical Electronics with a monochromatic $\mathrm{Al} \mathrm{K} \alpha$ source $(1486.6 \mathrm{eV})$ and a base pressure below $810^{-9}$ mbar. Survey spectra were recorded with an energy step size of $0.4 \mathrm{eV}$ and a pass energy of $93.90 \mathrm{eV}$ after $20 \mathrm{~s}$ of pre-sputtering in order to clean the surface before spectra acquisition. An ion neutralizer using $\mathrm{Ar}^{+}$of $\approx 1 \mathrm{eV}$ was used to minimize the fluctuations of the binding energy values due to possible sample charging. Elemental peaks of the sample surveys were annotated using the Multipak software.

Electrochemical testing.-Electrochemical testing was performed in a three-electrode electrochemical cell with liquid electrolyte. The cell was connected to a Squidstat potentiostat (Admiral Instruments) inside an argon-filled glovebox (Inert Corp.) at $30{ }^{\circ} \mathrm{C} .{ }^{22,23}$ Lithium foil (Sigma Aldrich) was used as counter and reference electrode. The electrolyte was propylene carbonate with $1.0 \mathrm{M} \mathrm{LiClO}_{4}$ (Sigma Aldrich). Cathode loading was calculated using the target density $\left(4.9 \mathrm{~g} \mathrm{~cm}^{-3}\right)$, the film thickness $(300 \mathrm{~nm})$ and the area of the electrochemical cell $\left(0.9 \mathrm{~cm}^{2}\right)$. The cell setup was clamped on the cathode using a Viton O-ring for sealing the aperture, thereby defining the active area of the half-cell. After equilibration, electrochemical impedance spectra (EIS) were acquired by charging the cells to $4 \mathrm{~V}$ at $1 \mathrm{C}\left(=22.0 \mu \mathrm{A} \mathrm{cm}^{-2}\right)$ and then stabilizing the potential until the current was below $1.1 \mu \mathrm{A} \mathrm{cm}^{-2}$. Following, a cyclic voltammetry $(\mathrm{CV})$ scan was performed between $3.0 \mathrm{~V}$ and $4.25 \mathrm{~V}$ at a rate of $0.25 \mathrm{mV} \mathrm{s}^{-1}$. The cells were then cycled by applying constant charge and discharge currents at $1 \mathrm{C}$, $2 \mathrm{C}, 5 \mathrm{C}, 10 \mathrm{C}, 50 \mathrm{C}, 100 \mathrm{C}$ and $1 \mathrm{C}$ for five times respectively in the range of $3 \mathrm{~V}$ to $4.25 \mathrm{~V}$. For lifetime assessment, the cells were cycled at $10 \mathrm{C}$ for 1000 cycles. At the beginning and after each 100 cycles, EIS was measured as described above.
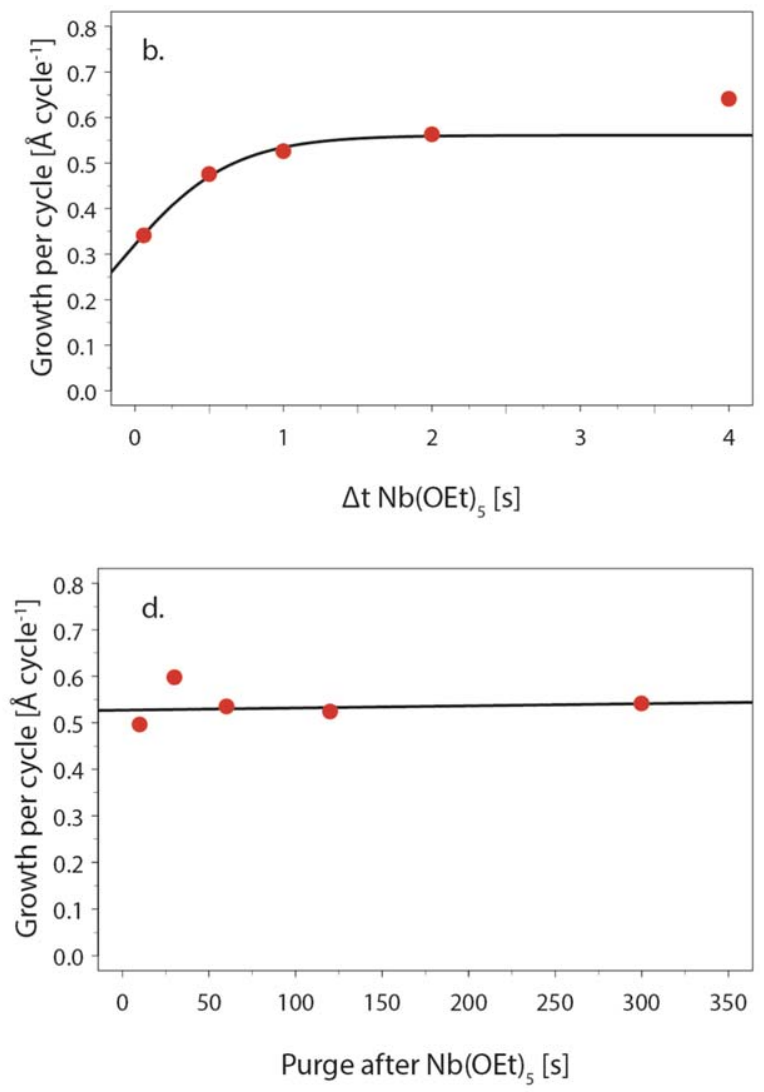

Figure 1. (a) Film thickness vs number of applied cycles. (b) Precursor saturation studies by variation of the $\mathrm{Nb}\left(\mathrm{OEt}_{5}\right)$ pulse length at $175{ }^{\circ} \mathrm{C}$ on $\mathrm{Si}(100)$. (c) Growth per cycle as a function of deposition temperature. (d) Growth per cycle variation with $\mathrm{Nb}\left(\mathrm{OEt}_{5}\right)$ purge time at $175^{\circ} \mathrm{C}$ on $\mathrm{Si}(100)$. $\mathrm{Black}$ lines serve as guide to the eye. 
a.
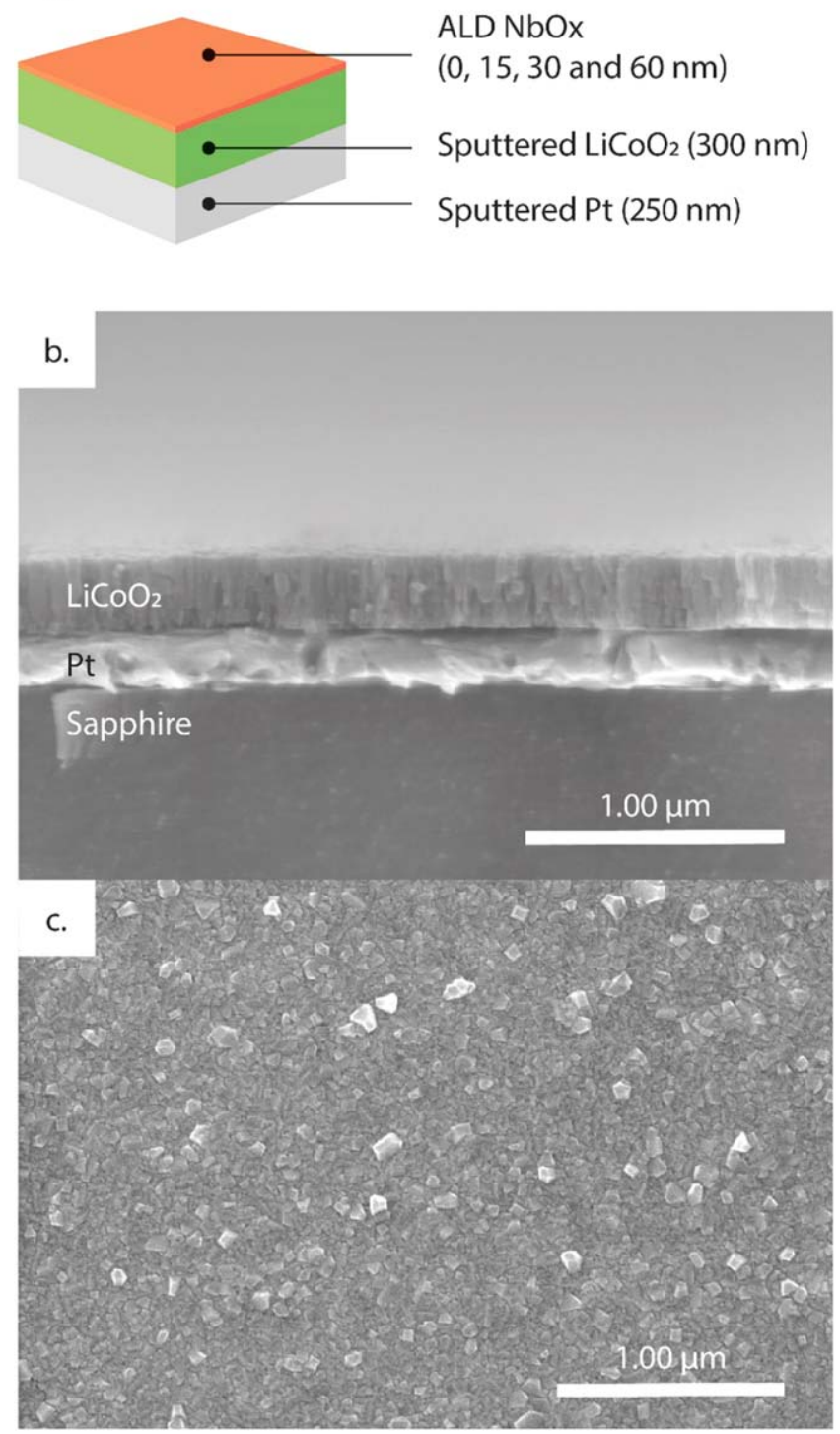

Figure 2. (a) Schematic of the investigated thin-film architecture. (b) Crosssection SEM image of the half-cell stack $\left(\mathrm{LiCoO}_{2} / \mathrm{Pt} / \mathrm{Ti} / \mathrm{sapphire}\right)$ without coating. (c) Surface SEM image of uncoated $\mathrm{LiCoO}_{2}$ on $\mathrm{Pt}$.

\section{Results and Discussion}

Atomic layer deposition of $\mathbf{N b O}_{\boldsymbol{x}}$. $-\mathrm{NbO}_{\mathrm{x}}$ layers were deposited by ALD on amorphous sputtered LCO thin films at a deposition temperature of $175{ }^{\circ} \mathrm{C}$. Fig. 1a shows the saturation curves for the ALD process. In Fig. 1a the linear growth under optimized conditions $\left(175{ }^{\circ} \mathrm{C}, 2 \mathrm{~s}\right.$ pulse time and $60 \mathrm{~s}$ purge time) was confirmed at a rate of $0.42 \AA$ cycle $^{-1}$ on silicon. Figure $1 \mathrm{~b}$ shows the saturation curve for the pulse time of $\mathrm{Nb}(\mathrm{OEt})_{5}$. Pulse time correlates directly with the amount of $\mathrm{Nb}(\mathrm{OEt})_{5}$ used and between one and three seconds of pulse time growth rate is not affected by the amount of precursor, whereas below one second and at four seconds deviation in the growth per cycle is observed. For all further runs a pulse time of $2 \mathrm{~s}$ was used. Similarly, Fig. 1c shows the deposition temperature vs growth rate, from which $175{ }^{\circ} \mathrm{C}$ was chosen. Figure $1 \mathrm{~d}$ shows the purge time necessary after the $\mathrm{Nb}(\mathrm{OEt})_{5}$ pulse, where below $50 \mathrm{~s}$ fluctuations in the growth rate were observed, resulting from remaining precursor in the chamber. $60 \mathrm{~s}$ purge time for the final process were selected. Three different coatings were prepared: $15 \mathrm{~nm}, 30 \mathrm{~nm}$ and $60 \mathrm{~nm}$, and compared to uncoated LCO. The procedure was for all four samples the same and only varied in the coating thickness. After the ALD deposition the cathodes were annealed at $700{ }^{\circ} \mathrm{C}$. The impedance of the cell decreases from about $40 \mathrm{k} \Omega \mathrm{cm}^{2}$ to below $200 \Omega \mathrm{cm}^{2}$ when the $\mathrm{NbO}_{\mathrm{x}}$ coating is annealed together with the LCO film compared to the as-deposited $\mathrm{NbO}_{\mathrm{x}}$ on already crystallized LCO films (Fig. S2). This suggests that the $\mathrm{NbO}_{\mathrm{x}}$ coating gets lithiated during the annealing, becoming Li-ion conductive in the process. From the EIS measurements an ionic conductivity for the lithiated $\mathrm{NbO}_{\mathrm{x}}$ coating in the order of $10^{-7} \mathrm{~s} \mathrm{~cm}^{-1}$ is estimated. XRD (Fig. S3) measurements confirm that as-deposited $\mathrm{NbO}_{\mathrm{x}}$ is amorphous and partially crystallizes after annealing at $700{ }^{\circ} \mathrm{C}$.

$\mathrm{NbO}_{x}$ coated LCO cathodes: Morphology, crystal phase and composition.-The schematic of the investigated thin-film cathode structure is depicted in Fig. 2a. Figure 2b presents an SEM crosssection image of the LCO thin film with the Pt current collector on sapphire substrate after annealing for $1 \mathrm{~h}$ at $700{ }^{\circ} \mathrm{C}$. The thickness is about $300 \mathrm{~nm}$. The characteristic columnar microstructure perpendicular to the substrate of LCO after heat treatment is observed, as also described in other publications. ${ }^{24}$ Figure $2 \mathrm{c}$ depicts a top-view image of the LCO film with the typical crystalline morphology after thermal annealing.

In Fig. 3a, the XRD patterns of $30 \mathrm{~nm} \mathrm{NbO}$-coated LCO films are compared with the XRD patterns of an uncoated film. The reflection indicated by a black arrow represents the $\mathrm{Nb}_{2} \mathrm{O}_{5}$ phase. The broadness of the reflection is attributed to a poor crystallinity of the annealed film. This agrees with previous reports of surface modification with niobium compounds ${ }^{25}$ and the reflection observed of annealed $\mathrm{ALD} \mathrm{NbO}_{\mathrm{x}}$ on Si-wafer (Fig. S3). Figure 3a exhibits the (003) oriented hexagonal LCO, with a strong reflection at around $18^{\circ} .^{24}$ Interestingly, the crystallinity of the coated LCO seems to be improved compared to the uncoated film, evidenced by a more intense and sharp (003) reflection.

Figure $3 \mathrm{~b}$ displays the ToF-SIMS depth profile of the main negatively ionized chemical species, namely $\mathrm{NbO}^{-}, \mathrm{LiO}^{-}, \mathrm{CoO}^{-}$ and $\mathrm{Pt}^{-}$The oxide species were analyzed instead of the pure elements due to a higher sensitivity. A partial diffusion of niobium into the bulk is observed because of the simultaneous annealing of the $\mathrm{NbO}_{\mathrm{x}}$ coating and the as-deposited LCO layer. On the surface, the higher intensity of the $\mathrm{NbO}^{-}$signal indicates that the coating is still present after annealing. The signal increase of the $\mathrm{LiO}^{-}$ correlates with the peak of the $\mathrm{NbO}^{-}$signal indicating the lithiation of the $\mathrm{NbO}_{\mathrm{x}}$ coating. Overall an interplay of $\mathrm{Nb}$ doping into the LCO cathode bulk and a surface effect is therefore expected. Figure $3 \mathrm{c}$ shows the full XPS survey surface spectra from 0 to $1400 \mathrm{eV}$ of $30 \mathrm{~nm} \mathrm{NbO}$ coated LCO cathodes annealed together. Figures $3 \mathrm{~d}-3 \mathrm{f}$ compare detailed XPS elemental peaks of as-deposited ALD $\mathrm{NbO}_{\mathrm{x}}$ on pre-annealed LCO (left) and LCO cathodes annealed with the $\mathrm{NbO}_{\mathrm{x}}$ coating (right). The collected spectra correspond to surface (top), $0.5 \mathrm{~min}, 1 \mathrm{~min}$ and $1.5 \mathrm{~min}$ (bottom) sputter time respectively. The estimated sputter rate is about $10 \mathrm{~nm} \mathrm{~min}^{-1}$. Figure $3 \mathrm{~d}$ shows an increased $\mathrm{I}(\mathrm{Li} 1 \mathrm{~s}) / \mathrm{I}(\mathrm{Nb} 4 \mathrm{~s})$ signal intensity ratio for $\mathrm{NbO}_{\mathrm{x}}$ samples annealed together with the cathode (right) compared to as-deposited $\mathrm{NbO}_{\mathrm{x}}$ (left). A direct comparison of the peak ratio is possible, since in $\mathrm{Nb} 4 \mathrm{~s}$ and Li1s the electrons originate in both cases from the $\mathrm{S}$ shell. ${ }^{26}$ The increased ratio indicates a higher lithium content in the case where the $\mathrm{NbO}_{\mathrm{x}}$ layer is annealed with the cathode. As discussed earlier, this results in a strong decrease in interface resistance compared to as-deposited $\mathrm{NbO}_{\mathrm{x}}$ on annealed $\mathrm{LCO}$ (Fig. S2). In Fig. 3e a shift to lower binding energies is observed for the Nb3d doublet peak, in the case where the coating is annealed together with the cathode. This indicates an overall lower oxidation state in the $\mathrm{Nb}-\mathrm{O}$ system due to a higher lithium content and presence of Li-bounded $\mathrm{NbO}_{\mathrm{x}}$ species within the sputtered layer thickness. The Nb3d detailed spectra for the as-deposited $\mathrm{NbO}_{\mathrm{x}}$ (Fig. 3e, left) displays an emerging peak shoulder at lower binding energy $(\sim 205 \mathrm{eV})$ with increasing sputter time, i.e. closer distance to the lithium containing cathode. This peak indicates limited lithium diffusion from the pre-annealed cathode into the as-deposited $\mathrm{NbO}_{\mathrm{x}}$ coating. Figure $3 \mathrm{f}$ shows at the surface (top) a peak at $532 \mathrm{eV}$, which 
a.

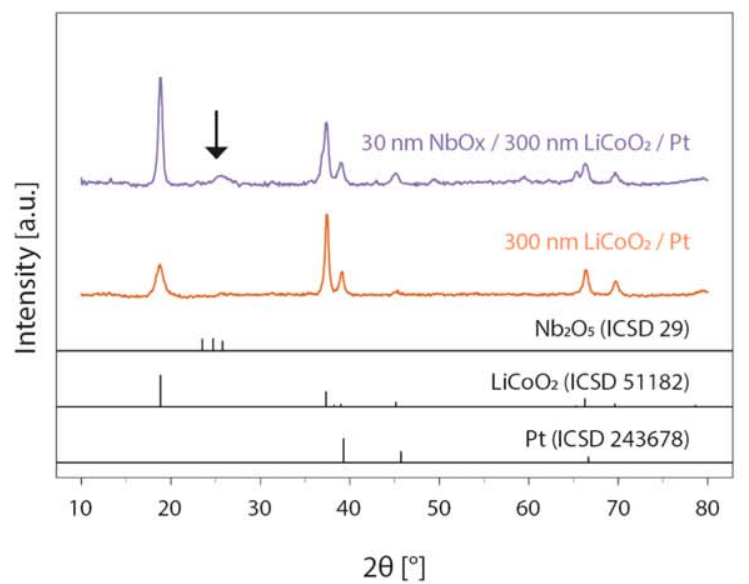

c.

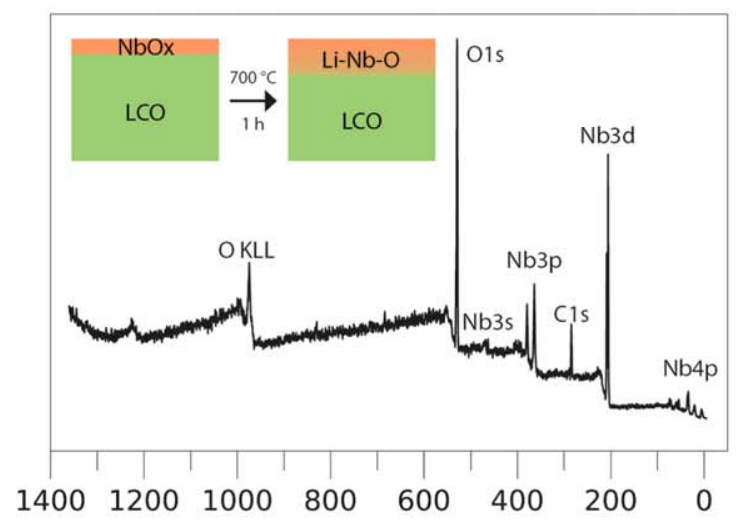

Binding energy [eV]

e.

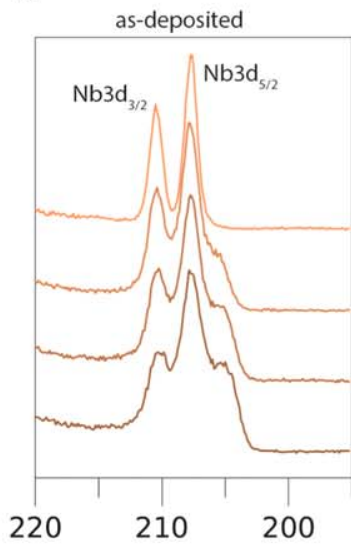

Binding energy [eV]

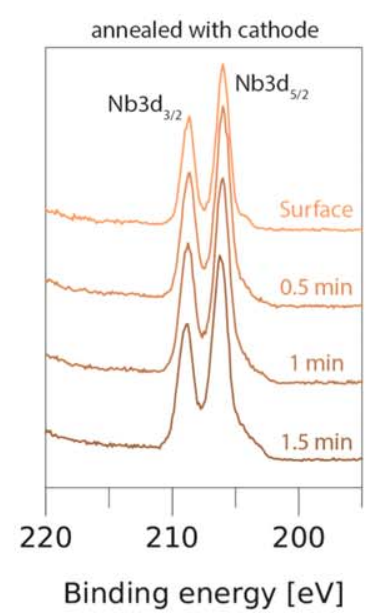

b.

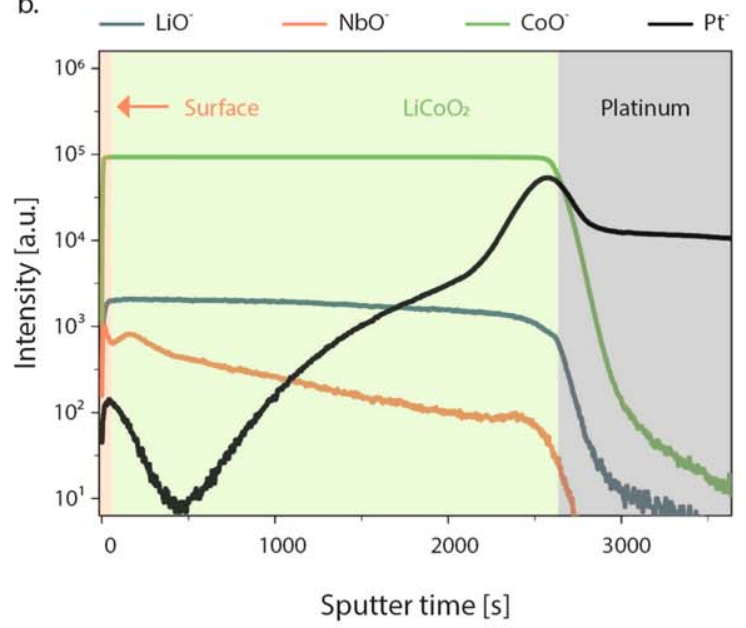

d.

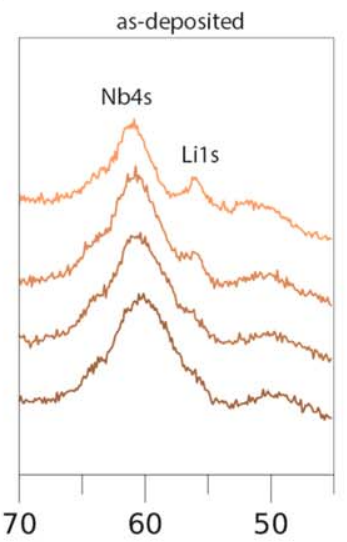

Binding energy [eV]

f.

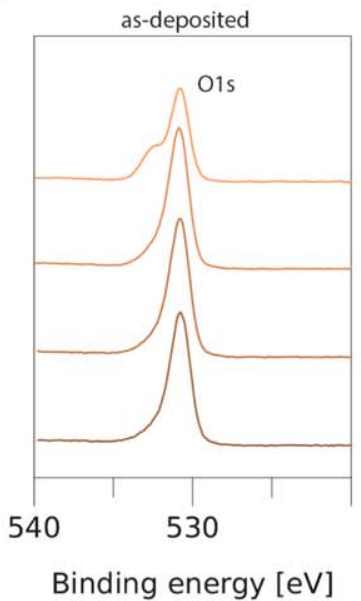

Binding energy [eV]

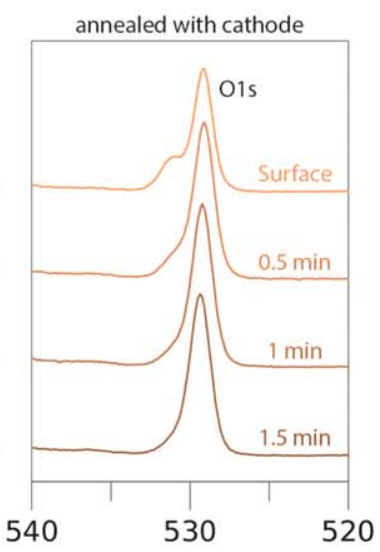

Binding energy [eV]

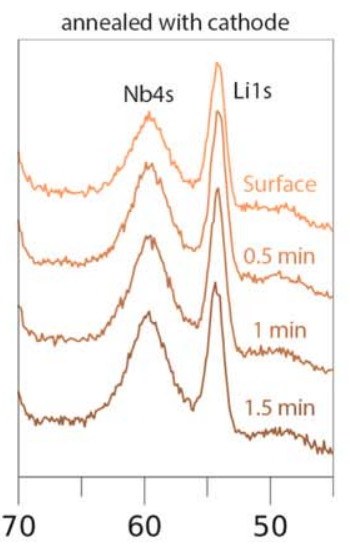

Figure 3. (a) Grazing-incidence $\mathrm{XRD}$ patterns of $\mathrm{LiCoO}_{2}$ on $\mathrm{Pt}$ with and without $\mathrm{NbO}_{\mathrm{x}}$ coating and annealed at $700{ }^{\circ} \mathrm{C}$ for $1 \mathrm{~h}$ under oxygen flow. The black arrow indicates the position of the $\mathrm{Nb}_{2} \mathrm{O}_{5}$ reflection. (b) ToF-SIMS depth profile of the ALD-NbO $(30 \mathrm{~nm})$ coated LiCoO $\mathrm{O}_{2}$ film after annealing. (c) XPS survey spectrum of $30 \mathrm{~nm} \mathrm{NbO}$ coated $\mathrm{LiCoO}_{2}$ cathode films after annealing measured from 0 to $1350 \mathrm{eV}$; Inset: schematic of the lithiation process during annealing of the coated cathode films. Detailed XPS peaks of Li1s and $\mathrm{Nb} 4 \mathrm{~s}(\mathrm{~d}), \mathrm{Nb3d}$ (e) and O1s (f) taken from as-deposited $\mathrm{NbO}_{\mathrm{x}}$ on $\mathrm{LCO}^{(\mathrm{eft})}$ and $\mathrm{NbO}_{\mathrm{x}}$ annealed together with the LCO cathode film (right) with no sputtering, $0.5 \mathrm{~min}, 1 \mathrm{~min}$ and $1.5 \mathrm{~min}$ sputter time from top to bottom.

vanishes after sputtering and corresponds to adsorbed oxygen. The structural oxygen peak (left $-531 \mathrm{eV}$ and right $-529 \mathrm{eV}$ ) remains through the whole layer, with a shift towards lower binding energy in the case of the $\mathrm{NbO}_{\mathrm{x}}$ layer annealed with the cathode due to the above-mentioned lithiation.
Electrochemical properties of the $\mathrm{NbO}_{x}$ coated cathodes.-The electrochemical properties were tested in a three electrode half-cell setup as depicted in the schematic in Fig. 4a. This approach allows the investigation of the cathode/electrolyte interface in a well understood and reproducible system. A propylene carbonate (PC) 

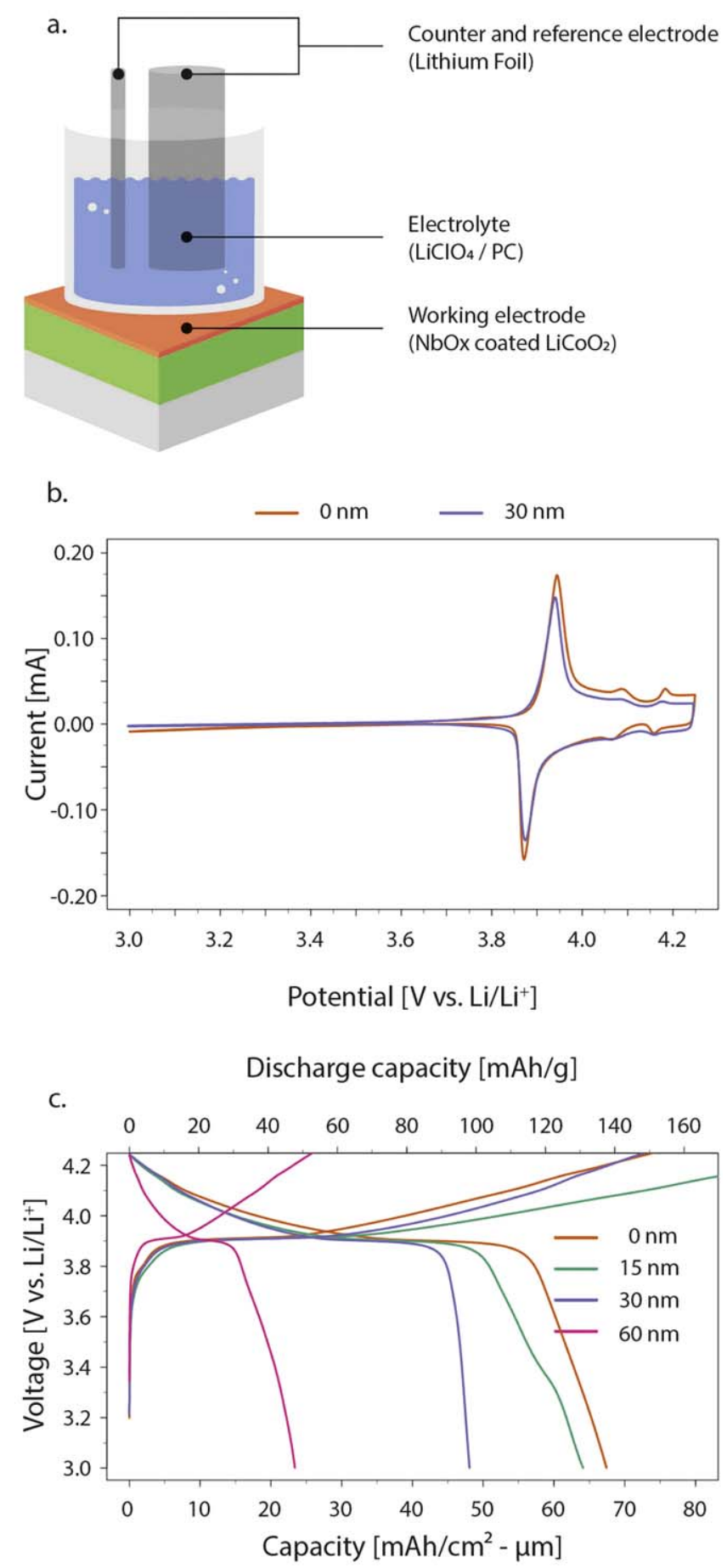

Figure 4. (a) Schematic illustration of the coated cathode assembled in a three-electrode half-cell configuration (b) Cyclic voltammetry between 3.0 and $4.25 \mathrm{~V}$ of $\mathrm{LiCoO}_{2}(0 \mathrm{~nm} \mathrm{NbO})$ and $\mathrm{LiCoO}_{2}(30 \mathrm{~nm} \mathrm{NbO})$. (c) Second cycle charge-discharge curves of bare and $\mathrm{NbO}_{\mathrm{x}}$-coated $\mathrm{LiCoO}_{2}$ at $1 \mathrm{C}$.

based electrolyte was used due to suitable ionogenic properties and a high dielectric constant. Since metallic lithium was used as counterand reference electrode, the usually unfavorable passivation of graphite was not an issue. ${ }^{27}$

Figure $4 \mathrm{~b}$ displays the cyclovoltammograms of the bare and $30 \mathrm{~nm} \mathrm{NbO}$ coated LCO thin films after cell assembly at a scan rate of $0.25 \mathrm{mV} \mathrm{s}^{-1}$. The main peak observed around $3.9 \mathrm{~V}$ corresponds to the lithium de- and intercalation. The smaller peaks around $4.0 \mathrm{~V}$ and $4.2 \mathrm{~V}$ correspond to the phase transition between the hexagonal and monoclinic phase. ${ }^{22}$ There is no significant difference for the peak position of the coated and uncoated films, however the peak intensity is lower, which can be attributed to an increase in the charge-transfer resistance due to the $30 \mathrm{~nm} \mathrm{NbO}_{\mathrm{x}}$ film. No additional redox peaks are observed, demonstrating no undesired side reactions in this first cycle. The main-peak splitting of $70 \mathrm{mV}$ indicates a low polarization of the system.

Figure $4 \mathrm{c}$ displays the full charge-discharge curves of the second cycle measured at $1 \mathrm{C}$ between $3.00 \mathrm{~V}$ and $4.25 \mathrm{~V}$. All capacities are given both in $\mathrm{mAh} \mathrm{g}^{-1}$ and $\mathrm{mAh} \mathrm{cm}^{2}-\mu \mathrm{m}$ to facilitate comparison with other reported thin-film cathodes. The latter dimension represents the areal capacity independent of the cathode film thickness and does not require assumptions on the film porosity. In agreement with the $\mathrm{CV}$ measurements, the charge-discharge curves possess a characteristic plateau at $3.9 \mathrm{~V}$ as expected from the lithiation and delithiation of LCO. The discharge capacity decreases with increasing coating thickness. This might be due to lithiation of the film coating taking place in the first cycles, using up more lithium with increasing film thickness. Additionally, it is possible that the coating and surface doping binds lithium and forms non-active phases, which again would lead to a decreased capacity. Simultaneously, decreased columbic efficiency is observed for samples having a thicker $\mathrm{NbO}_{\mathrm{x}}$ coating, supporting lithium loss as explanation for the lower discharge capacities (Fig. S5).

Charge transfer resistance for different $\mathrm{NbO}_{x}$ coating thicknesses.-EIS measurements were performed to understand the ion dynamics and extract the charge transfer resistance from the equivalent circuit in the insert of Fig. 5a by fitting to the measured electrochemical impedance spectra. The employed equivalent circuit is commonly used to model coated LCO cathodes. ${ }^{28}$ Figure 5a presents the impedance spectra of bare and $\mathrm{NbO}_{\mathrm{x}}$-modified LCO thin film electrodes. In the high and medium frequency range two semicircles can be observed for all the samples. The first semicircle in the high frequency region is attributed to the lithium ion diffusion across the electrode-electrolyte interphase. The second circle is related to the charge transfer region between the surface film and the active material interphase, as discussed in other publications. ${ }^{29}$

Figure $5 \mathrm{~b}$ displays the total resistance of the cells. Of note is that the $30 \mathrm{~nm}$ coated sample possesses the lowest total resistance, but this is due to the series resistance having the main contribution to $\mathrm{R}_{\text {tot }}$. The initial charge-transfer resistance for the $30 \mathrm{~nm}$ coated sample is the highest of all the samples, but due to its low absolute value this is not reflected in the total resistance.

Rate performance of the half-cells.-Figure 6a presents the discharge capacity for different $\mathrm{C}$ rates of the cathode films with different $\mathrm{NbO}_{\mathrm{x}}$ coatings. Measurement was performed five times at each C-rate, ranging from $1 \mathrm{C}\left(=22.0 \mu \mathrm{A} \mathrm{cm}^{-2}\right)$ and up to an ultrafast rate of $100 \mathrm{C}\left(=2203.3 \mu \mathrm{A} \mathrm{cm}^{-2}\right)$. In the end the measurement at $1 \mathrm{C}$ was repeated for each cell, to rule out degradation as cause of the decreased capacity at high currents. Discharge capacities of the early cycles are unstable due to initial lithiation and SEI formation. After measuring at $2 \mathrm{C}$ the discharge capacities tend to stabilize. As expected, discharge capacity decreased with increasing C-rate because of higher polarization, however to a different extend. When compared to the uncoated cathode, the $15 \mathrm{~nm}$ coated LCO cathode shows a similar rate performance, while the cycle life increases from 193 to 273. We speculate that co-annealing the $\mathrm{NbOx}$ coating with the cathode results in only a partially coated cathode for the $15 \mathrm{~nm}$ sample. While this partial coating would help to protect the interface during cycling, it does not provide the necessary continuous film for facilitated ion movement across the interface, which is necessary for high rate performance. For $30 \mathrm{~nm}$ and $60 \mathrm{~nm}$ coated samples the behavior is drastically different from uncoated LCO films. The $30 \mathrm{~nm}$ coated sample exhibits an excellent rate performance, surprisingly even at $100 \mathrm{C} 47 \%$ remaining initial capacity is observed. It is 

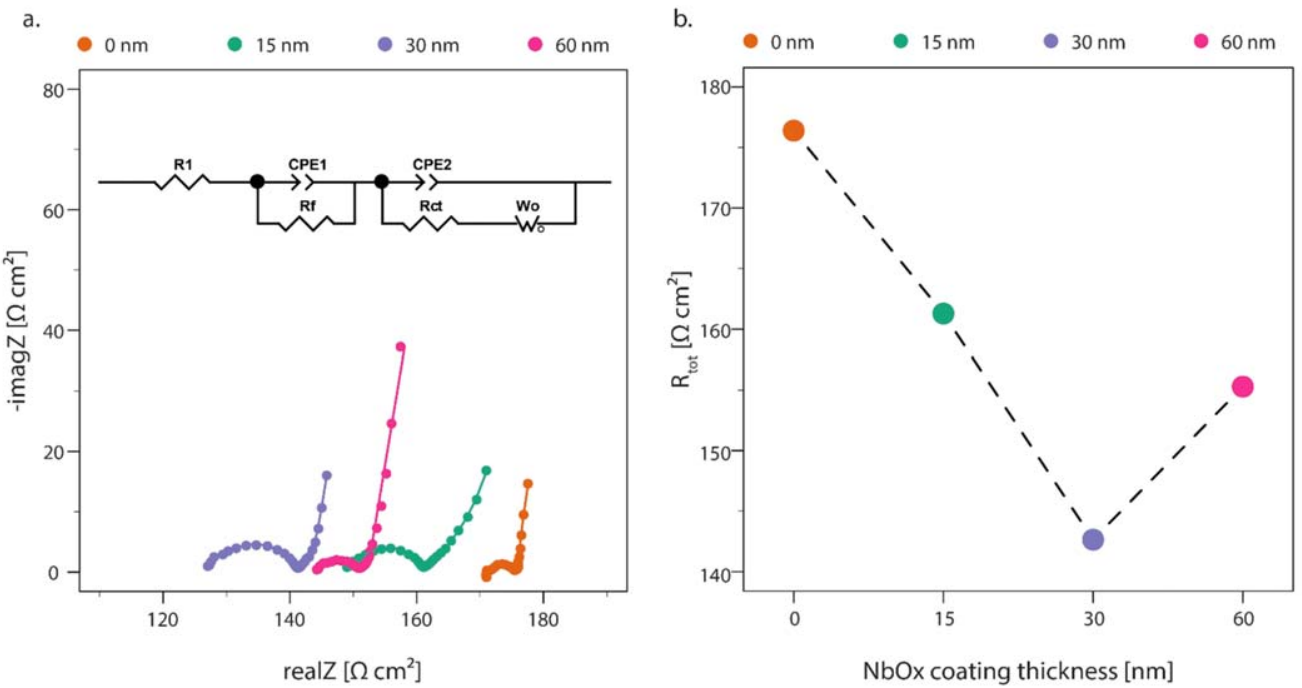

Figure 5. (a) Nyquist plots of the as-assembled cells with different $\mathrm{NbO}_{\mathrm{x}}$ coating thicknesses in the frequency range of $0.1 \mathrm{~Hz}$ to $1000 \mathrm{kHz}$. Measured data and the equivalent circuit (inset) fit are depicted. (b) Total cell resistance as a function of the coating thickness of the as-assembled cells.

commonly reported that the effect of the cathode coating becomes more pronounced at elevated current rates, ${ }^{30}$ however the extent of the increase shows the importance of the coating thickness on rate performance of the cathode. No remaining capacity is observed for all other samples at $100 \mathrm{C}$. After the rate performance measurement, the capacity returns almost to its initial values when cycling the film again at $1 \mathrm{C}$. This indicates that for all besides the $30 \mathrm{~nm} \mathrm{NbO}$ coated sample, lithium intercalation is not possible under larger currents as a result of high overpotentials. Figure $6 \mathrm{~b}$ and $\mathrm{c}$ display the chargedischarge curves at different $\mathrm{C}$ rates for the uncoated and the $30 \mathrm{~nm}$ coated sample. The curves at high and low C-rates are of the same shape indicating that the main lithiation and delithiation process does not change with the applied current.

The initial capacity gap between the uncoated and the $30 \mathrm{~nm}$ sample is inverted at higher $\mathrm{C}$ rates, and consequently an increase in the coulombic efficiency observed. For low $\mathrm{C}$ rates, all samples display the characteristic slope and plateau region from 3.0 to $4.25 \mathrm{~V}$. At higher $\mathrm{C}$ rates the discharge capacity of the uncoated sample deteriorates fast, whereas the $30 \mathrm{~nm}$ sample possesses low capacity degradation up to $10 \mathrm{C}$.

To study the degradation behavior, all cells were cycled at $10 \mathrm{C}$ for 1000 cycles after the rate-performance measurements. Figure $7 \mathrm{a}$ displays the measured discharge capacity normalized to the initial value. The $\mathrm{NbO}_{\mathrm{x}}$ coating has a strong influence on the cycle life, as seen in the cycle life ( $80 \%$ remaining capacity) plotted in the inset of Fig. 7a. By coating the cathode with $30 \mathrm{~nm} \mathrm{NbO}_{\mathrm{x}}$ it was possible to increase the cycle life at $10 \mathrm{C}$ from less than 200 cycles for uncoated cathodes to 493 cycles.
The Nyquist plots of the impedance spectra measured after each 100 cycles depicted in Fig. $7 b$ and c visualize the effect of the $\mathrm{NbO}_{\mathrm{x}}$ coating on mitigating the resistance increase. While the uncoated sample demonstrates impedance growth over two orders of magnitude, the $30 \mathrm{~nm} \mathrm{NbO}_{\mathrm{x}}$-coated cathode film presents a significantly slower degradation pace. To quantify the degradation extent, the equivalent circuit parameters (see Fig. 5a) were extracted from the impedance spectra measured every 100 cycles. As depicted in Fig. $7 \mathrm{~d}$, the charge transfer resistance decreases with increasing coating thickness. However, one needs to carefully balance the decreased capacity with the gain from charge-transfer reduction. In our measurements $30 \mathrm{~nm} \mathrm{NbO}$ seems to be optimal, whereas $15 \mathrm{~nm}$ coated sample displays behavior close to uncoated samples, and $60 \mathrm{~nm}$ samples suffer too much from decreased capacity.

\section{Discussion}

Table I presents different inorganic coatings on thin-film LCO, with transition-metal oxides being the most common material. The thickness of the coating material differs widely among different publications, ranging from an order of magnitude thinner (such as in this work) up to thicknesses above the cathode itself. ${ }^{14}$ The employed LCO thickness of $300 \mathrm{~nm}$ is comparable to other publications with exception of the $18 \mathrm{~nm}$ epitaxially grown film ${ }^{31}$ and the $4 \mu \mathrm{m}$ thick cathode employed by Lee et al. ${ }^{32}$ The capacity at $1 \mathrm{C}$ of the $30 \mathrm{~nm} \mathrm{NbO}$ coated LCO cathode is average with $45 \mu \mathrm{Ah} \mathrm{cm}^{-2}-\mu \mathrm{m}$ and lower than the theoretical capacity of LCO which lies above $60 \mu \mathrm{Ah} / \mathrm{cm}^{2}-\mu \mathrm{m}$, as earlier discussed. However,

Table I. Selected thin-film LCO cathode coatings.

\begin{tabular}{|c|c|c|c|c|c|c|c|c|}
\hline Coating & $\begin{array}{c}\text { Coating } \\
\text { thickness } \\
{[\mathrm{nm}]}\end{array}$ & $\begin{array}{c}\text { LCO } \\
\text { thickness } \\
{[\mathrm{nm}]}\end{array}$ & $\begin{array}{c}\text { Max. } \\
\text { capacity }(1 \mathrm{C}) \\
{\left[\mu \mathrm{Ah} \mathrm{cm}^{-2}-\mu \mathrm{m}\right]}\end{array}$ & $\begin{array}{l}\text { Max. C } \\
\text { rate }\end{array}$ & $\begin{array}{l}\text { Remaining } \\
\text { capacity at } \\
\text { max C [\%] }\end{array}$ & $\begin{array}{c}\mathrm{R}_{\mathrm{CT}} \text { with } \\
\text { coating } \\
{\left[\Omega \mathrm{cm}^{2}\right]}\end{array}$ & $\begin{array}{l}\text { Cycle life } \\
\text { [cycles] }\end{array}$ & References \\
\hline $\mathrm{MgO}$ (PLD) & - & - & - & - & - & 53 & - & 33 \\
\hline $\mathrm{LiTaO}_{3}(\mathrm{PLD})$ & 300 & 300 & 51 & 30 & 0 & 376 & - & 14 \\
\hline Li-Nb-O (PLD) & 350 & 300 & 49 & 30 & 20 & 239 & - & 14 \\
\hline Li-W-O (PLD) & 300 & 300 & 30 & 30 & 70 & 600 & $\sim 50(1 \mathrm{C})$ & 34 \\
\hline Li-W-O (PLD) & 300 & 300 & 45 & - & - & 51 & - & 35 \\
\hline $\mathrm{Li}_{2} \mathrm{ZrO}_{3}(\mathrm{PLD})$ & 0.4 & 18 (epitaxial) & 65 & 300 & 65 & 220 & - & 31 \\
\hline $\mathrm{ZrO}_{2}(\mathrm{PLD})$ & 120 & 500 & - & - & - & 1000 & $>20$ & 36 \\
\hline $\mathrm{MgF}_{2}$ (sol.) & - & 4000 & 50 & 3 & 71 & - & $20(1 \mathrm{C})$ & 32 \\
\hline $\mathrm{NbO}_{\mathrm{x}}(\mathrm{ALD})$ & 30 & 300 & 45 & 100 & 48 & 20 & 493 (10 C) & This work \\
\hline
\end{tabular}




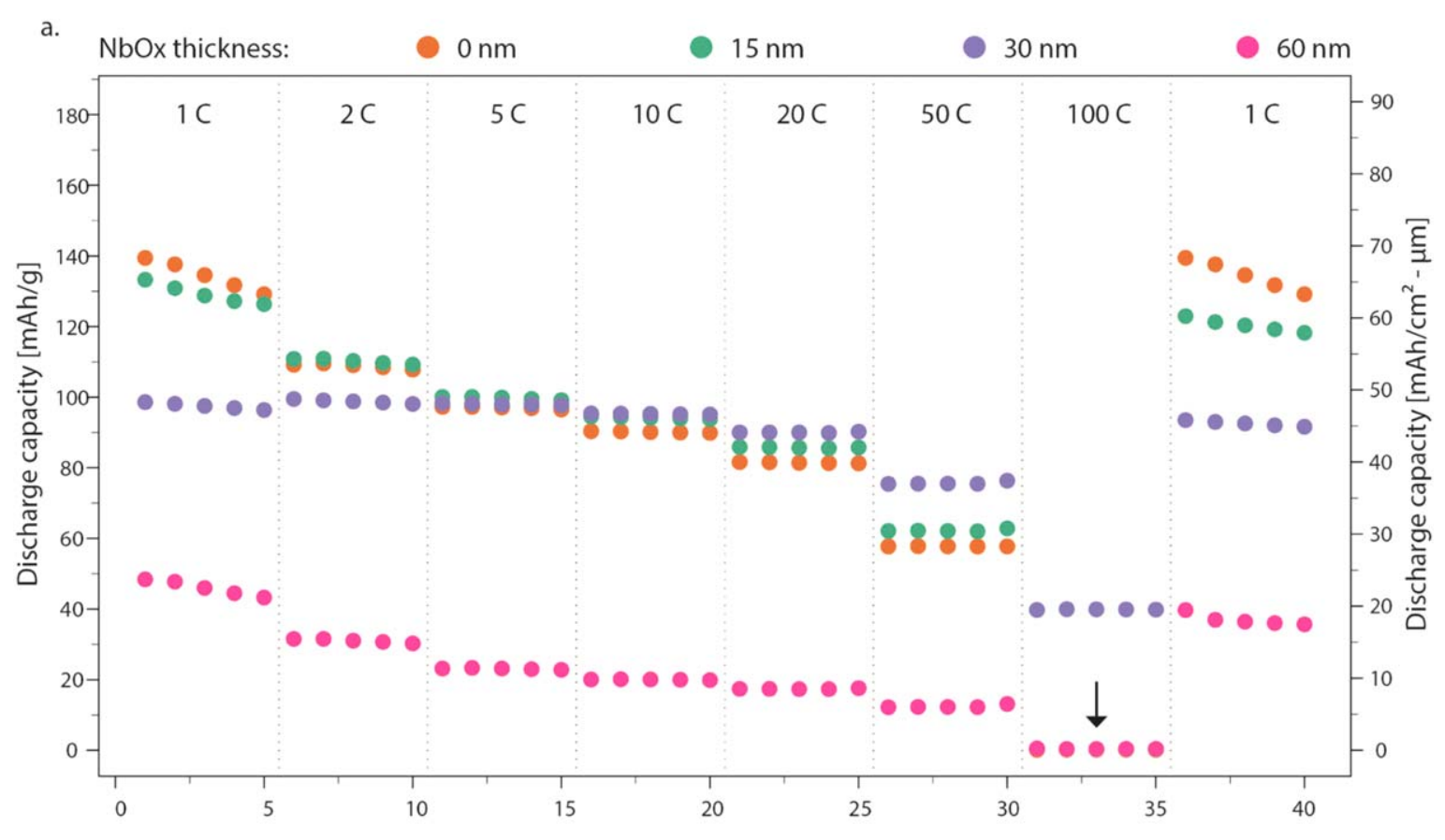

Cycle number

b.

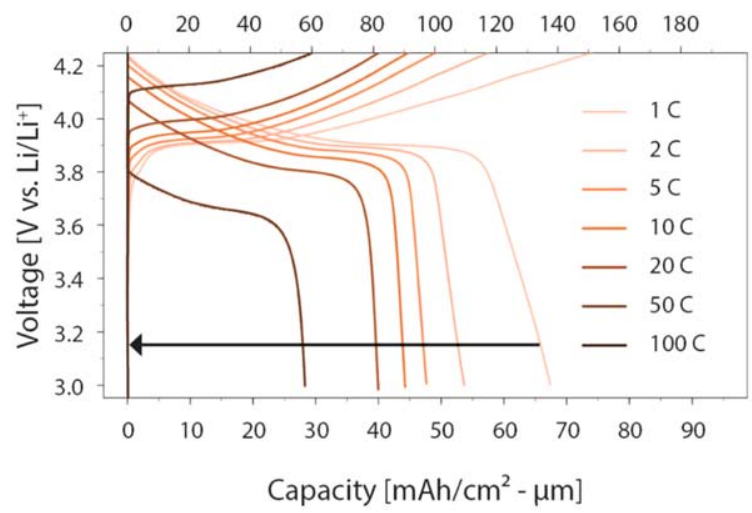

c.

Discharge capacity $[\mathrm{mAh} / \mathrm{g}]$

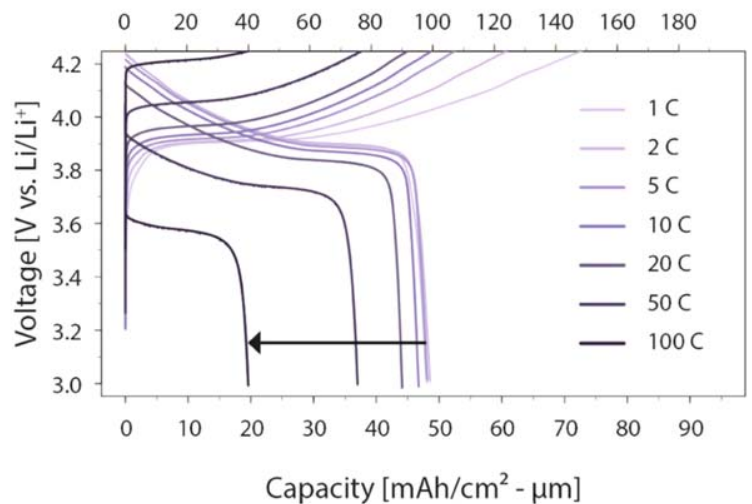

Figure 6. (a) Discharge capacity of $\mathrm{LiCoO}_{2}$ with different $\mathrm{NbO}_{\mathrm{x}}$ coating thicknesses at different $\mathrm{C}$ rates. The arrow indicates that the experimental points for 0 , 15 and $60 \mathrm{~nm}$ coating overlap at zero discharge capacity at $100 \mathrm{C}$. (b) Charge-discharge curves of bare $\mathrm{LiCoO}_{2}$. (c) Charge-discharge curves of $30 \mathrm{~nm}$ $\mathrm{NbO}_{x}$-coated $\mathrm{LiCoO}_{2}$. The arrow visualizes the capacity decrease with increasing C-rate.

the observed $47 \%$ remaining capacity at $100 \mathrm{C}$ is superior to other work except for the epitaxially grown LCO which shows better rate performance but is with a thickness of $18 \mathrm{~nm}$ considerably thinner. The charge transfer resistance of $20 \Omega \mathrm{cm}^{2}$ in our work appears to be the lowest reported value. The low initial resistance and the inhibition of the growth thereof results in superior cycle life of almost 500 cycles at $10 \mathrm{C}$.

Comparing $\mathrm{NbO}_{\mathrm{x}}$ to other inorganic coating materials is not straightforward since the LCO thickness and initial resistance plays an important role. This is expressed through the performance of the uncoated LCO employed in this work, which performs close to some of the coated LCO cathodes reported in Table I. Since the cathode coating often leads to an increase in charge transfer resistance, ${ }^{5}$ it is desirable to keep the coating as thin as possible. The coating should also be conformal to protect the rough cathode-electrolyte interface, thus favoring the use of ALD as a deposition technique. A better coverage of the cathode surface by ALD $\mathrm{NbO}_{\mathrm{x}}$ in this work can probably explain the superior electro-chemical performance as compared to PLD coatings.

\section{Conclusions}

An ALD process for $\mathrm{NbO}_{\mathrm{x}}$ coatings on layered cathode materials was developed and investigated in a thin-film model system, without binder and conductive additives. Annealing the as-deposited sputtered $\mathrm{LCO}$ cathode together with the $\mathrm{NbO}_{\mathrm{x}}$ coating results in $\mathrm{Nb}$ diffusion into the cathode with simultaneous in situ lithiation of the $\mathrm{NbO}_{\mathrm{x}}$ coating. This cross-diffusion improves the ionic conductivity of the coating but reduces the initial capacity of the LCO cathode. The lithiated coating mitigates interface degradation and consequently it slows down the growth of the charge-transfer resistance at the cathode-electrolyte interface. Both cycle life and rate performance of the coated cathode films showed a strong dependence on the coating thickness, with the optimal balance between the two found for a thickness of $30 \mathrm{~nm}$. These optimized films showed $80 \%$ remaining initial capacity after 500 cycles at $10 \mathrm{C}$, more than double that of the uncoated LCO, while maintaining an initial capacity close to $100 \mathrm{mAh} \mathrm{g}^{-1}$ at $10 \mathrm{C}$. The conformal nature of binary ALD coatings, together with precise thickness control, is an attractive 

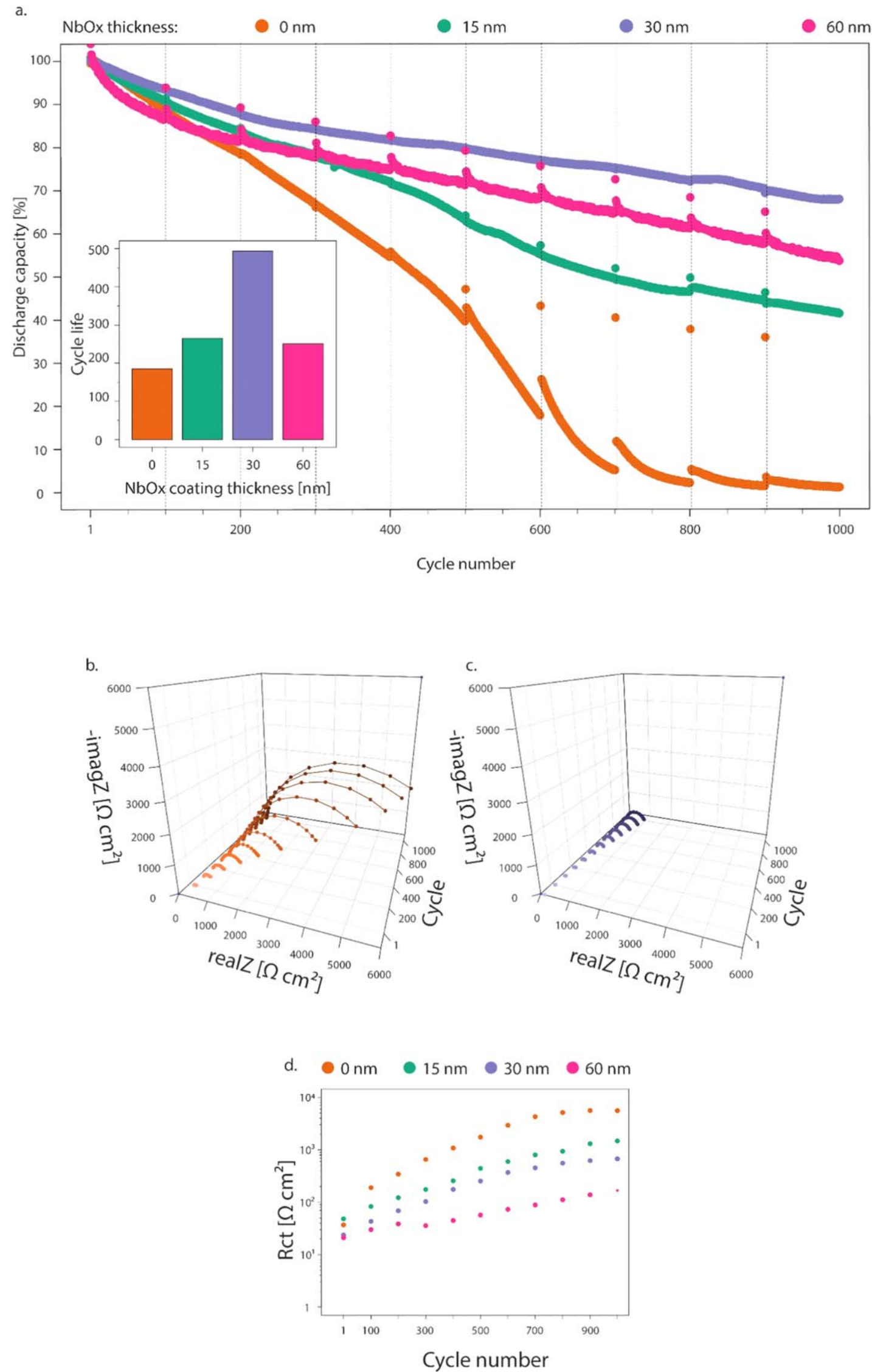

Figure 7. (a) Normalized discharge capacity at $10 \mathrm{C}$ over 1000 cycles. The grey vertical lines indicate the EIS experiment performed every 100 cycles. The inset depicts cycle life (at $20 \%$ capacity loss) for different $\mathrm{NbO}_{\mathrm{x}}$ coating thicknesses. (b) and (c): Nyquist plot of (b) uncoated $\mathrm{NbO}_{\mathrm{x}}$-coated $\mathrm{LCO}$ and (c) $\mathrm{NbO}_{\mathrm{x}}$-coated LCO during cycling. (d) Charge-transfer resistance evolution over 1000 cycles for different $\mathrm{NbO}_{\mathrm{x}}$ coating thicknesses. 
method for improving cycle life and high-rate performance of layered oxide cathode materials.

\section{Acknowledgments}

This work was supported by the Empa internal project "SUISSEbattery", the Swiss National Science Foundation [grant number 200021_172764], the Strategic Focus Area (SFA) Advanced Manufacturing of the ETH Domain (project "X-ray Diagnostics") and the joint Empa-Fraunhofer ISC project 'IE4B' under the ICON funding line. We acknowledge the Laboratory for Nanoscale Materials Science for the access to ToF-SIMS equipment.

\section{ORCID}

Abdessalem Aribia (D) https://orcid.org/0000-0002-5558-8345

Jordi Sastre (iD https://orcid.org/0000-0003-0866-0911

Evgeniia Gilshtein (iD https://orcid.org/0000-0001-5938-2523

Moritz H. Futscher (iD https://orcid.org/0000-0001-8451-5009

Yaroslav E. Romanyuk (iD https://orcid.org/0000-0002-0529-228X

\section{References}

1. C. Li, H. P. Zhang, L. J. Fu, H. Liu, Y. P. Wu, E. Rahm, R. Holze, and H. Q. Wu, Electrochim. Acta, 51, 3872 (2006).

2. L. Liu, M. Li, L. Chu, B. Jiang, R. Lin, X. Zhu, and G. Cao, Prog. Mater. Sci., 111100655 (2020)

3. M. K. Shobana, J Alloy Compd, 802, 477 (2019).

4. S. Zhang, J. Ma, Z. Hu, G. Cui, and L. Chen, Chem. Mater, 31, 6033 (2019).

5. K. Wang, J. Wan, Y. Xiang, J. Zhu, Q. Leng, M. Wang, L. Xu, and Y. Yang, J. Power Sources, 460, 228062 (2020).

6. M. Aykol, S. Kirklin, and C. Wolverton, Adv. Energy Mater., 4, 1400690 (2014)

7. S.-T. Myung, K. Amine, and Y.-K. Sun, J. Mater. Chem., 20, 7074 (2010).

8. K. Wang, S. P. Huang, Y. Wu, N. N. Cai, N. Li, Q. Xiao, and Z. Sun, Nanoscale, 11, 16277 (2019)

9. M. Du, K. Liao, Q. Lu, and Z. Shao, Energy Environ. Sci., 12, 1780 (2019).

10. Z. Chen, Y. Qin, K. Amine, and Y. K. Sun, J. Mater. Chem., 20, 7606 (2010).

11. M. Wei, K. Wei, M. Ichihara, and H. Zhou, Electrochem. Commun., 10, 980 (2008)

12. B. Wang, Y. Zhao, M. N. Banis, Q. Sun, K. R. Adair, R. Li, T. K. Sham, and X. Sun, ACS Appl. Mater. Interfaces, 10, 1654 (2018).
13. N. Ohta, K. Takada, I. Sakaguchi, L. Zhang, R. Ma, K. Fukuda, M. Osada, and T. Sasaki, Electrochem. Commun., 9, 1486 (2007).

14. M. Kato, T. Hayashi, G. Hasegawa, X. Lu, T. Miyazaki, Y. Matsuda, N. Kuwata, K. Kurihara, and J. Kawamura, Solid State Ionics, 308, 54 (2017).

15. W. D. Richards, L. J. Miara, Y. Wang, J. C. Kim, and G. Ceder, Chem. Mater., 28 , 266 (2015)

16. Y. Zhu, X. He, and Y. Mo, J. Mater. Chem. A, 4, 3253 (2016).

17. J. Sastre, X. Chen, A. Aribia, A. N. Tiwari, and Y. E. Romanyuk, ACS Appl. Mater. Interfaces, 12, 36196 (2020).

18. W. Sun, M. Xie, X. Shi, and L. Zhang, Mater. Res. Bull., 61, 287 (2015).

19. N. J. Dudney and Y.-I. Jang, J. Power Sources, 119-121, 300 (2003).

20. A. N. Filippin, T.-Y. Lin, M. Rawlence, T. Zünd, K. Kravchyk, J. Sastre-Pellicer S. G. Haass, A. Wäckerlin, M. V. Kovalenko, and S. Buecheler, RSC Adv., 8, 20304 (2018).

21. N. Doebelin and R. Kleeberg, J. Appl. Crystallogr., 48, 1573 (2015)

22. S. Takeuchi, H. Tan, K. K. Bharathi, G. R. Stafford, J. Shin, S. Yasui, I. Takeuchi, and L. A. Bendersky, ACS Appl. Mater. Interfaces, 7, 7901 (2015).

23. X. Chen and P. M. Vereecken, Adv. Mater. Interfaces, 4, 1600877 (2017).

24. C.-L. Liao and K.-Z. Fung, J. Power Sources, 128, 263 (2004).

25. T. Kato, T. Hamanaka, K. Yamamoto, T. Hirayama, F. Sagane, M. Motoyama, and Y. Iriyama, J. Power Sources, 260, 292 (2014).

26. E. A. Skryleva, I. V. Kubasov, P. V. Kiryukhantsev-Korneev, B. R. Senatulin R. N. Zhukov, K. V. Zakutailov, M. D. Malinkovich, and Y. N. Parkhomenko, Appl. Surf. Sci., 389, 387 (2016).

27. K. Kanamura, H. Takezawa, S. Shiraishi, and Z.i. Takehara, J. Electrochem. Soc., 144, 1900 (2019)

28. T. Hayashi, J. Okada, E. Toda, R. Kuzuo, Y. Matsuda, N. Kuwata, and J. Kawamura, J. Power Sources, 285, 559 (2015).

29. C.-C. Wang, J.-W. Lin, Y.-H. Yu, K.-H. Lai, K.-F. Chiu, and C.-C. Kei, Acs Sustain Chem Eng, 6, 16941 (2018)

30. Y. J. Kim, H. Kim, B. Kim, D. Ahn, J. G. Lee, T. J. Kim, D. Son, J. Cho, Y. W. Kim, and B. Park, Chem. Mater., 15, 1505 (2003).

31. A. Yano, K. Hikima, J. Hata, K. Suzuki, M. Hirayama, and R. Kanno, J. Electrochem. Soc., 165, A3221 (2018)

32. H. J. Lee and Y. J. Park, Solid State Ionics, 230, 86 (2013).

33. Y. Iriyama, H. Kurita, I. Yamada, T. Abe, and Z. Ogumi, J. Power Sources, 137 111 (2004).

34. T. Hayashi, Y. Matsuda, N. Kuwata, and J. Kawamura, J. Power Sources, 354, 41 (2017).

35. T. Hayashi, T. Miyazaki, Y. Matsuda, N. Kuwata, M. Saruwatari, Y. Furuichi, K. Kurihara, R. Kuzuo, and J. Kawamura, J. Power Sources, 305, 46 (2016).

36. J.-i. Inamoto, T. Fukutsuka, K. Miyazaki, and T. Abe, J. Appl. Electrochem., 47, 1203 (2017). 